\title{
$\beta$-Ti Alloys for Orthopedic and Dental Applications: A Review of Progress on Improvement of Properties through Surface Modification
}

\author{
Longfei Shao ${ }^{1,+}$, Yiheng Du ${ }^{1,+}$, Kun Dai ${ }^{1,+}$, Hong Wu ${ }^{2}$, Qingge Wang ${ }^{2, * D}$, Jia Liu ${ }^{3, *}$, Yujin Tang ${ }^{3, *}$ \\ and Liqiang Wang ${ }^{1, *}$
}

1 State Key Laboratory of Metal Matrix Composites, School of Material Science and Engineering, Shanghai Jiao Tong University, No. 800 Dongchuan Road, Shanghai 200240, China; shaolongfei@sjtu.edu.cn (L.S.); 03170813@sjtu.edu.cn (Y.D.); daikun1989@sjtu.edu.cn (K.D.)

2 State Key Lab of Powder Metallurgy, Central South University, Changsha 410083, China; hwucsu@csu.edu.cn

3 Affiliated Hospital of Youjiang Medical University for Nationalities, Baise 533000, China

* Correspondence: wendymewqg@163.com (Q.W.); liujia0111@live.cn (J.L.); tangyujin196709@163.com (Y.T.); wang_liqiang@sjtu.edu.cn (L.W.)

+ The authors contributed equally to this work as first authors.

\section{check for} updates

Citation: Shao, L.; Du, Y.; Dai, K.; Wu, H.; Wang, Q.; Liu, J.; Tang, Y.;

Wang, L. $\beta$-Ti Alloys for Orthopedic and Dental Applications: A Review of Progress on Improvement of Properties through Surface Modification. Coatings 2021, 11, 1446. https://doi.org/10.3390/ coatings11121446

Academic Editors: Joel Rech and Eugenio Velasco-Ortega

Received: 6 October 2021

Accepted: 22 November 2021

Published: 25 November 2021

Publisher's Note: MDPI stays neutral with regard to jurisdictional claims in published maps and institutional affiliations.

Copyright: (C) 2021 by the authors. Licensee MDPI, Basel, Switzerland. This article is an open access article distributed under the terms and conditions of the Creative Commons Attribution (CC BY) license (https:/ / creativecommons.org/licenses/by/ $4.0 /)$.
Abstract: Ti and Ti alloys have charming comprehensive properties (high specific strength, strong corrosion resistance, and excellent biocompatibility) that make them the ideal choice in orthopedic and dental applications, especially in the particular fabrication of orthopedic and dental implants. However, these alloys present some shortcomings, specifically elastic modulus, wear, corrosion, and biological performance. Beta-titanium $(\beta$-Ti) alloys have been studied as low elastic modulus and low toxic or non-toxic elements. The present work summarizes the improvements of the properties systematically (elastic modulus, hardness, wear resistance, corrosion resistance, antibacterial property, and bone regeneration) for $\beta$-Ti alloys via surface modification to address these shortcomings. Additionally, the shortcomings and prospects of the present research are put forward. $\beta$-Ti alloys have potential regarding implants in biomedical fields.

Keywords: beta titanium alloy; elastic modulus; wear resistance; corrosion property; surface modification; osseointegration

\section{Introduction}

Titanium and its alloys have been widely used as bone implants in clinical dentistry and orthopedics, especially $\mathrm{CP} \mathrm{Ti}(\alpha)$ and Ti-6Al-4V $(\mathrm{TC} 4, \alpha+\beta)$ [1]. However, the development of CP Ti and TC4 was restricted because of high elastic modulus and toxic element vanadium (V). Low elastic modulus and non-toxic $\beta$-Ti alloys were designed to solve these problems. $\beta$-Ti alloys majorly represented a $\beta$-phase-dominated microstructure after annealing and air cooling to room temperature with the BCC form of titanium (called beta). The alloying elements in the titanium matrix can be one or more of these metals, including molybdenum (Mo), vanadium $(\mathrm{V})$, niobium $(\mathrm{Nb})$, tantalum $(\mathrm{Ta})$, zirconium $(\mathrm{Zr})$, manganese $(\mathrm{Mn})$, iron $(\mathrm{Fe})$, chromium $(\mathrm{Cr})$, cobalt $(\mathrm{Co})$, nickel $(\mathrm{Ni})$, and copper $(\mathrm{Cu})$ [2-4]. The combination of different types and contents of elements leads to a variety of $\beta$-Ti alloys with distinct properties; the resultant $\beta$-Ti alloys usually have excellent formability and facile welding characteristics $[5,6]$.

As shown in Table 1, these Ti alloys have been applied as implants in clinical surgery. Nevertheless, the low wear resistance of Ti alloys became the new issue. Researchers developed varieties with modified processing and technology to enhance the wear resistance and endowed $\beta$-Ti alloys with antibacterial properties and bone regeneration. 
Table 1. The uses, advantages, and disadvantages of Ti and its alloys.

\begin{tabular}{|c|c|c|c|c|c|c|}
\hline Materials & Type & Advantages & Disadvantages & Applications & $\begin{array}{l}\text { Clinical } \\
\text { Surgery }\end{array}$ & Ref. \\
\hline $\mathrm{CP} \mathrm{Ti}$ & $\alpha$ & Good biocompatibility & $\begin{array}{l}\text { Low strength and poor } \\
\text { wear resistance }\end{array}$ & Dental implants & $\sqrt{ }$ & {$[7]$} \\
\hline Ti-3Al-2.5V & $\alpha+\beta$ & $\begin{array}{l}\text { Good strength and } \\
\text { corrosion resistance }\end{array}$ & Toxicity elements (Al, V) & Dental implants & $\sqrt{ }$ & [8] \\
\hline $\begin{array}{l}\text { Ti-6Al-4V } \\
\text { (TC4) }\end{array}$ & $\alpha+\beta$ & $\begin{array}{l}\text { Excellent strength and } \\
\text { corrosion resistance }\end{array}$ & $\begin{array}{c}\text { High elastic modulus, } \\
\text { toxicity elements (Al, V), } \\
\text { and poor wear resistance }\end{array}$ & $\begin{array}{c}\text { Bone fixation plates } \\
\text { and stem of artificial } \\
\text { hip joints }\end{array}$ & $\sqrt{ }$ & [1] \\
\hline $\mathrm{Ti}-6 \mathrm{Al}-7 \mathrm{Nb}$ & $\alpha+\beta$ & Good wear resistance & Toxicity element (Al) & $\begin{array}{l}\text { Dental prostheses } \\
\text { knee, wrist, and } \\
\text { femoral stems, } \\
\text { fasteners, fixation } \\
\text { plates, and screws }\end{array}$ & $\sqrt{ }$ & [9] \\
\hline $\mathrm{Ti}-5 \mathrm{Al}-2.5 \mathrm{Fe}$ & $\alpha+\beta$ & Good wear resistance & Toxicity element (Al) & Hip prostheses & $\sqrt{ }$ & {$[1]$} \\
\hline $\begin{array}{l}\text { Ti-2.5Al-2.5Mo- } \\
\text { 2.5Zr (TAMZ) }\end{array}$ & $\alpha+\beta$ & $\begin{array}{l}\text { High compatibility, } \\
\text { toughness, fatigue resistance }\end{array}$ & Toxicity element (Al) & $\begin{array}{c}\text { Hip stems, } \\
\text { endosseous, } \\
\text { subperiosteal, or } \\
\text { transosteal implants } \\
\text { in dentistry }\end{array}$ & $\sqrt{ }$ & {$[10]$} \\
\hline $\begin{array}{l}\text { Ti-12Mo-6Zr- } \\
\text { 2Fe (TMZF) }\end{array}$ & $\beta$ & $\begin{array}{l}\text { Low elastic modulus, high } \\
\text { fracture toughness, good } \\
\text { wear resistance, and } \\
\text { corrosion resistance }\end{array}$ & $\begin{array}{c}\text { Head-neck taper fretting } \\
\text { and corrosion, } \\
\text { flexural rigidity }\end{array}$ & $\begin{array}{l}\text { Femoral neck shaft, } \\
\text { acetabular implant, } \\
\text { and femoral stems }\end{array}$ & $\sqrt{ }$ & [11] \\
\hline $\mathrm{Ti}-13 \mathrm{Nb}-13 \mathrm{Zr}$ & near $\beta$ & $\begin{array}{c}\text { Low elastic modulus, low } \\
\text { density, paramagnetic } \\
\text { properties, low } \\
\text { thermal conductivity }\end{array}$ & $\begin{array}{l}\text { Low hardness } \\
\text { and resistance }\end{array}$ & $\begin{array}{l}\text { Head and } \\
\text { acetabulum of hip } \\
\text { endoprostheses }\end{array}$ & $\sqrt{ }$ & [12] \\
\hline $\begin{array}{l}\text { Ti-24Nb-4Zr- } \\
\text { 8Sn (Ti2448) }\end{array}$ & $\beta$ & $\begin{array}{l}\text { High biocompatibility and } \\
\text { mechanical properties }\end{array}$ & Low wear resistance & $\begin{array}{l}\text { Artificial hip joints } \\
\text { and dental roots }\end{array}$ & $\sqrt{ }$ & {$[13,14]$} \\
\hline Ti-15Mo & $\beta$ & $\begin{array}{l}\text { More biocompatible, } \\
\text { lower modulus, } \\
\text { better processability }\end{array}$ & Lower strength & $\begin{array}{l}\text { Femoral hip } \\
\text { implant components }\end{array}$ & $\sqrt{ }$ & [15] \\
\hline $\mathrm{Ti}-28 \mathrm{Nb}-24.5 \mathrm{Zr}$ & $\beta$ & $\begin{array}{l}\text { Low elastic modulus, } \\
\text { high strength and } \\
\text { toughness, excellent } \\
\text { mechanical properties } \\
\text { and biocompatibility }\end{array}$ & Poor wear property & $\begin{array}{l}\text { Surgical and } \\
\text { orthopedic implants }\end{array}$ & $\sqrt{ }$ & [16] \\
\hline
\end{tabular}

The elastic modulus is one of the most specific mechanical characteristics and among the vitally prominent physical indicators that substantially affect the long-term stability of implants in medical applications. In this regard, the maximum elastic modulus of human bone is $15-30 \mathrm{GPa}$, while the elastic modulus of CP Ti (100 GPa) and TC4 (112 GPa) is far higher than that of human bone [1]. The elastic modulus of $\beta$-Ti is more than $50 \mathrm{GPa}$, which is higher than that of human bone [17-20]. Because of the mismatch in stiffness, most of the stress is concentrated on the implants. Human bone grows and rebuilds during the whole process. Thus, the bone density may decrease due to a lack of load in the long-term surrounding the implants, which causes bone resorption or nonunions and a stress shielding phenomenon while affecting usual recovery [21]. On the other hand, low elastic modulus material will severely deform after being stressed and lose its supporting effect [22]. Moreover, achieving an intimate attachment of implanted Ti alloys to the biological tissue is challenging and may lead to implant fracture and fall off the tissue. Thus, it is necessary to explore the relationship between the elastic modulus and chemical 
composition, hardness, and porosity. To overcome the issue regarding stress shielding, different chemical compositions and microstructures of $\beta$-Ti alloys were developed; some of them have been used in the biomedical field (Table 1), and some are still at the research stage. In Figure 1, some researchers reported an approach to control the elastic modulus by designing the material microstructures. Hardness improvement without affecting other properties is of particular importance in $\beta$-Ti alloys for implants $[23,24]$.

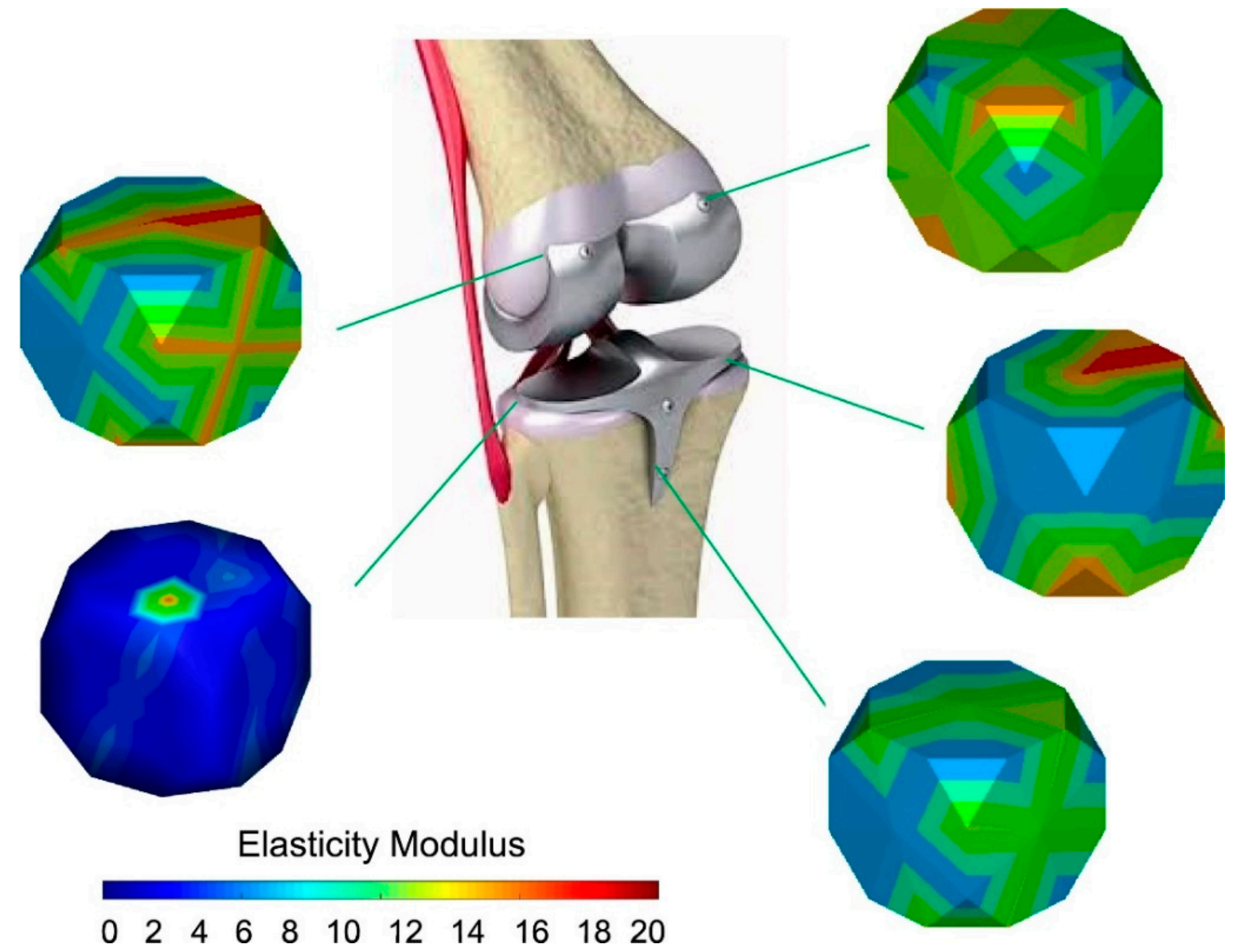

Figure 1. Design of the elastic modulus by changing the material microstructures. Reproduced with permission from [25], copyright Elsevier, 2020.

The Ti alloys always present low wear resistance. The high coefficients of friction and large wear loss are considered as the negative factors of the tribological behaviors. Although there is high corrosion resistance, the protective oxide layer on the surface of Ti alloys can be destroyed during infection in body fluid with low oxygen content and biomolecules. The wear and tear of the prosthetic components (femoral head and cup of a hip implant) creates metallic wear debris with the size of $0.05 \mu \mathrm{m}$ that leads to adverse cellular responses, toxicity, and inflammation, ultimately causing osteolysis, implant loosening, or the formation of a pseudo-tumor [26-29]. The wear debris percentage is about $4 \%-5 \%$ of all the implant failure cases.

The electrochemical performance (corrosion resistance) of Ti and its alloys' implants has a decisive role in human health. In the body fluid environment, the toxic ions (for example, $\mathrm{Co}, \mathrm{Cr}, \mathrm{Ni}, \mathrm{Al}$, and $\mathrm{V}$ ions) release into the surrounding tissues and even organs by body fluids via corrosion, increasing the risk of cytotoxic and even genotoxic and allergic responses in medical implantation. The corrosion of objects may produce adverse effects, reduce the implant life, and endanger the safety of human life. In addition, the implants may cause failure due to corrosion-fatigue under the effect of cyclically load. The reason for corrosion failure is related to implant design. The number and size of defects (including 
porosity, grain, and inclusions) decides the quality of implants. Due to the micro-current effects between the different phases and almost non-toxic elements, $\beta$-Ti alloys have broad prospects in biomedicine compared with other Ti alloys [29].

Another crucial requirement for long-term implant stability is related to their favorable biological response. In this regard, bacterial infection is one of the main reasons for the failure of Ti alloys in human implants [30]. It is reported that the implants' failure rate reaches $0.5 \%-5 \%$ due to bacterial infection [29]. Regarding bacterial infection, particular pathogens result in biofilms and microbial reproduction on the surface of implants after adhering, colonizing, and proliferating, leading to bone destruction [31]. The biofilm is hard to remove, which results in revision surgeries. In order to promote the biomedical application of $\beta$-Ti alloys, it is of crucial importance to increase the antibacterial abilities of $\beta$-Ti alloys.

The excellent bone regeneration decides the stability and service life of implants. Generally, Ti and Ti alloys are bio-inert [32]. The factors affecting the bone regeneration process are the patient's age and bone quality, and anatomical location [29]. The elastic modulus, hardness, wear resistance, and corrosion resistance may cause low bone-implant contact then implant failure.

Hence, these properties are mutually influencing and closely connected. The stress shielding, toxicity, and poor wear resistance are difficult to overcome [33]. Developing novel $\beta$-Ti alloys without toxic elements is the only choice to solve these problems. The elastic modulus of $\beta$-Ti is lower than other Ti alloys implants. Moreover, the wear resistance can be improved by surface modification.

There are many literature studies that have reported a variety of methods for addressing these shortcomings, such as substrate (surface) modification methods and deposition of surface coatings. The common surface modification techniques involve in friction stir processing (FSP), ultrasonic nanocrystal surface modification (UNSM), laser surface treatment (LST), surface mechanical attrition treatment (SMAT), and equal channel angular pressing (ECAP). The surface coating deposition methods include chemical vapor deposition (CVD), acid and alkali treatment [34], evaporation, sputtering, and laser cladding [35,36]. The exclusive focus of the present review is the literature on the surface modification methods.

In the recent literature, there are many review articles on $\mathrm{Ti}$ alloys and on $\mathrm{Ti}$ alloys for biomedical applications via the surface modification method to improve their properties $[1,37,38]$. The previous reviews did not focus exclusively on orthopedic and dental applications and did not focus exclusively on substrate (surface) modification methods but also included coating deposition methods.

The purpose of the review is to perform a critical review of the literature on the surface modification methods, with an emphasis on the improvement in the hardness, wear resistance, friction coefficient, corrosion resistance, antibacterial activity, and bone regeneration performance of $\beta$-Ti alloys in orthopedic and dental applications. Moreover, the review also includes a brief discussion of the shortcomings of this body of literature.

\section{Elastic Modulus}

In the field of orthopedic implants, elastic modulus is one of the most crucial physical indicators. The maximum elastic modulus of human bone is $30 \mathrm{GPa}$, while the elastic modulus of Ti alloy is generally above $80 \mathrm{GPa}$. A high elastic modulus of a metallic implant will cause stress shielding and affect normal recovery [39]. The "stress shielding" effect is associated with the disproportional load distribution between a bone and an adjacent implant due to the elastic modulus mismatch. The metallic implant materials are usually considerably stiffer as compared to bones. Eventually, the elastic modulus mismatch may lead to bone resorption and loosening or failure of the implant. The elastic modulus of $\beta$-Ti alloys matches with cortical bone. In addition, porous Ti alloys are found to potential choices to develop low elastic modulus Ti alloys [40-43]. The elastic modulus of common $\beta$-Ti alloys is summarized in Figure 2. 


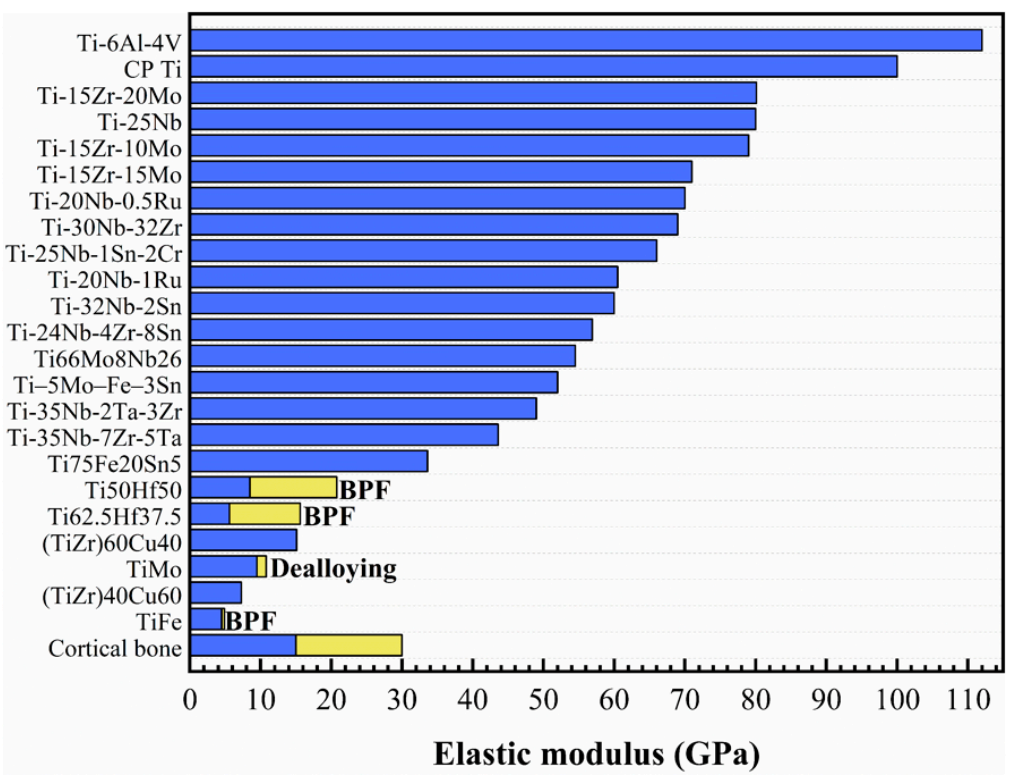

Figure 2. The elastic modulus of different composition and modified $\beta$-Ti alloys (BPF -impregnated by bisphenol F epoxy resin). Reprinted with permission from ref. [40,44-50]. Copyright Elsevier, 2018, 2019, 2020, and 2021.

Modern surface modification treatments, such as dealloying, have been proven to reduce the elastic modulus and nonporous structure [51,52]. Okulov et al. [53] synthesized the Ti-Mg interpenetrating phase composite material with a low elastic modulus by liquid metal dealloying. The elastic modulus (17.6 GPa) of the composite material was several times lower than those of the individual component phase, namely $\mathrm{Mg}$ (45 GPa) and Ti (110 GPa). In another study, they [43] developed a design strategy of light-weight nano-/microporous alloys by selective corrosion in liquid metal. The elastic modulus could be adjusted between 4.4 and $24 \mathrm{GPa}$, which affords matching to bone.

In fact, low elastic modulus material deforms easily after being stressed [46]. Thus, Ti alloys are difficult to closely adhere to the biological tissue. Eventually, the implants break and fall off from the tissue. It is vital to keep the elastic modulus in an appropriate range.

\section{Hardness}

There are many ways to measure the hardness of materials with their specific mechanical meanings, such as Brinell, Vickers, and nano-indentation methods. As shown in Figure 3 , the hardness of unstrengthened $\beta$-Ti alloy is much higher than human materials, such as bones and femurs [24]. The combination of high hardness, low elastic modulus, and excellent biocompatibility is desirable but difficult to achieve simultaneously, so it is of great importance to improve the hardness without reducing other properties.

Heat treatment plays a vital part in the improvement of hardness. It is reported that Ti-xNb-3Zr-2Ta alloys $(x=33,31,29,27,25)(w t . \%)$ were carried out by water quenching and air cooling, respectively. The hardness value of both the water quenching and aircooling group enhanced significantly with the reduction in niobium content. However, there are two different mechanisms to increase the hardness between water quenching and air cooling. For the water quenching group, with the volume fractions of the martensite phase, the hardness increased. For the air cooling group, the improvement of hardness was attributed to the lattice distortion of the $\beta$ matrix [54]. 


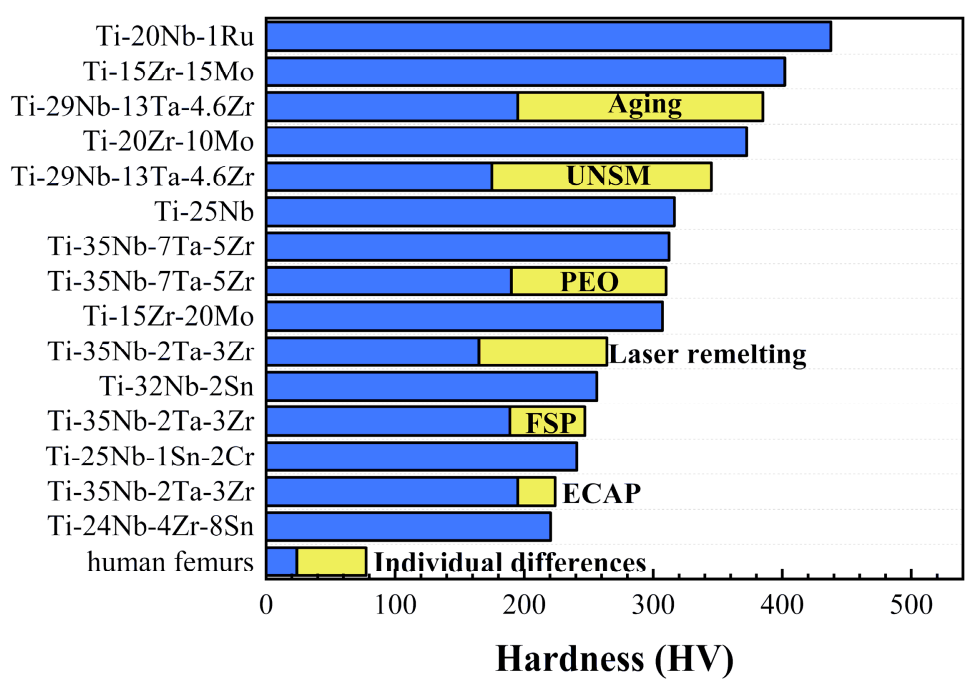

Figure 3. The hardness of different composition and modified $\beta$-Ti alloys. Reprinted with permission from ref. [45,55-60]. Copyright Elsevier, 2003, 2013, 2015, 2019, and 2021.

FSP, as a novel solid-state surface modification technique, is an attractive method for inducing localized thermomechanical effects [61]. In order to modify the surface of the newly developed Ti-35Nb-2Ta-3Zr (wt.\%) alloy, Wang et al. [56] explored the microhardness value of deformation pass from single pass to three passes at the same rotation speed. The microhardness increased from 189 HV to 208 HV via FSP. After three passes, the microhardness was up to $247 \mathrm{HV}$. In addition, the ECAP method can produce considerable uniform plastic strains to refine grains and enhance mechanical properties. It is reported that the hardness values of $\beta \mathrm{Ti}-35 \mathrm{Nb}-3 \mathrm{Zr}-2 \mathrm{Ta}$ biomedical alloy with refined grains and uniform microstructures after four passes reached $216 \mathrm{HV}$. Moreover, a low elastic modulus of about 59 GPa was obtained [59].

Niinomi et al. [62] reported that TNTZ could effectively inhibit bone atrophy and enhance bone remodeling in vivo. Additionally, TNTZ exhibits a low elastic modulus that is approximately half of TC4 $[63,64]$. However, due to its relatively low wear resistance, TNTZ cannot satisfy the requirements for biomedical implants [65]. Hence, there is a substantial motivation to improve the wear resistance of TNTZ by increasing the hardness while maintaining its relatively low elastic modulus. The TNTZ samples after aging exhibited varying hardness values at different temperatures. Within a definite temperature range, the hardness increased as the temperature rose.

The UNSM technique as a branch of the physical methods is controlled by a computer numerical system. Therefore, innovative processed surfaces with complex geometric shapes and microstructures can be created via accurate parameter selection to improve the properties of surfaces [60]. Besides, researchers investigating the performance of coatings on the surface of Ti alloys have proposed various schemes to compensate for some of the shortcomings of Ti alloys [66,67]. Kheradmandfard et al. [68] processed the TNTZ alloy with the UNSM technique to enhance its hardness. The result showed that the hardness at the surface improved from $195 \mathrm{Hv}$ to $385 \mathrm{Hv}$; by moving away from the surface, the rate of increase in surface hardness decreases. However, the reason for the hardness increment by UNSM is attributed to grain refinement and a working hardening phenomenon. It was seen that the samples have a thin diffusion layer with a weak bonding to the substrate after diffusion [67].

Chauhan et al. [69] used laser surface heat treatment (LST) to modify the surface microstructure of VT3- $\alpha-\beta$-Ti alloy. LST was carried out at various laser powers $(100-250 \mathrm{~W})$ and scanning speeds of $150-500 \mathrm{~mm} / \mathrm{min}$. EBSD)analysis of the laser-affected zone exhibited a distinct microstructure across the depth of the specimen, and it changed with laser power and scanning speed. At a lower scanning speed $(150 \mathrm{~mm} / \mathrm{min})$ and high laser power 
$(200 \mathrm{~W})$, an almost complete $\beta$-containing microstructure was developed at the surface with a high hardness level of $750 \mathrm{Hv}$. Obtaining dendritic microstructure and homogenous elemental distribution is helpful in hardness improving.

A laser was also used in the study of remelting on Ti-35Nb-2Ta-3Zr by Zhang et al. [58]. It was found that the average microhardness value increased from $165 \mathrm{Hv}$ up to $264 \mathrm{Hv}$, which could be ascribed to the surface of the material changing from an equiaxed crystal to a needle-like structure after laser remelting.

Most of research is concentrated on improving the hardness of $\beta$-Ti alloys by thermomechanical effects. The use of more advanced digital control systems to accurately select parameters for processing, which includes heat treatment and complex microstructure building, may be a further development direction.

\section{Wear Resistance}

Generally, medical Ti alloys show poor wear properties, and it is easy to become worn in the human body [70-72]. Prosthetic components' wear will produce pieces, causing adverse cellular behavior and inflammatory reactions, eventually leading to implant loosening [17]. The presence of particle corrosion and wear products in the surrounding tissues of implants may cause osteoporosis and eventually lead to the failure of implants [73]. Therefore, it is important to clarify the wear mechanism and find the solution to increase wear resistance.

The wear mechanisms of $\mathrm{Ti}$ alloys mainly include oxidation wear, adhesive wear, abrasive wear, and layered wear. However, different loading sliding velocities, matrix material, and ambient temperature conditions will change the wear mechanism [74-76]. According to Archard's laws, the sliding wear resistance is proportional to the alloy hardness [77]. Additionally, the friction coefficient can also affect the wear resistance of the material. Generally, a low friction coefficient is beneficial to the wear resistance of the material. Some researchers designed $\beta$-Ti via modification processes to decrease the friction coefficient on the material surface, as shown in Table 2. 
Table 2. Summary of preparation process and tribological performance.

\begin{tabular}{|c|c|c|c|c|c|c|c|}
\hline \multirow{2}{*}{ Material } & \multirow{2}{*}{ Preparation Process } & \multicolumn{2}{|c|}{ Coefficient of Friction } & \multicolumn{2}{|c|}{ Wear Loss } & \multirow{2}{*}{ Mechanism } & \multirow{2}{*}{ Ref. } \\
\hline & & Before & After & Before & After & & \\
\hline Ti-24Nb-38Zr-2Mo & $\begin{array}{l}\text { cold crucible levitation melting + cold rolling + } \\
\text { solution treatment }\end{array}$ & 1.25 & 1.10 & $1.3 \mathrm{mg}$ & $0.9 \mathrm{mg}$ & $\begin{array}{l}\text { plowing and some indication of } \\
\text { abrasive wear }\end{array}$ & [78] \\
\hline Ti-24Nb-38Zr-2Mo-0.1Sc & $\begin{array}{c}\text { cold crucible levitation melting + cold rolling + } \\
\text { solution treatment }\end{array}$ & 1.20 & 0.90 & $1.0 \mathrm{mg}$ & $0.5 \mathrm{mg}$ & $\begin{array}{l}\text { plowing and some indication of } \\
\text { abrasive wear }\end{array}$ & {$[78,79]$} \\
\hline Ti-35Nb-2Ta-3Zr & hybrid surface modification & 0.6 & 0.15 & / & l & abrasive wear + adhesive wear & [31] \\
\hline Ti-13Zr-13Nb-0.5B & $\begin{array}{c}\text { melting }+ \text { heat treatment }+ \text { hot rolling }+ \text { solid } \\
\text { solution }+ \text { water quenching }\end{array}$ & 0.42 & 0.4 & / & / & microcutting; abrasive wear & [73] \\
\hline $\mathrm{Ti}-29 \mathrm{Nb}-13 \mathrm{Ta}-4.6 \mathrm{Zr}$ & Picosecond + laser processing & / & / & $0.00102 \mathrm{~mm}^{3}$ & $0.00014 \mathrm{~mm}^{3}$ & $\begin{array}{l}\text { wear debris containment effect and } \\
\text { loading pressure }\end{array}$ & {$[79,80]$} \\
\hline Ti-25Nb-3Zr-2Sn-3Mo & vacuum induction nitriding & 0.65 & 0.25 & $0.2 \mathrm{~mm}^{3}$ & $0.0007 \mathrm{~mm}^{3}$ & $\begin{array}{l}\text { abrasive wear (rod-shaped TiN0.3 } \\
\text { phase and soft } \beta \text { matrix) }\end{array}$ & {$[80]$} \\
\hline Ti-5Al-5Mo-5V-3Cr-0.5Fe & vacuum arc melting + forging + stress relaxation & 0.57 & 0.45 & $0.073 \mathrm{~mm}^{3}$ & $0.034 \mathrm{~mm}^{3}$ & $\begin{array}{l}\text { small amount of adhesive wear and } \\
\text { slight abrasion wear }\end{array}$ & {$[81]$} \\
\hline $\mathrm{Ti}-29 \mathrm{Nb}-13 \mathrm{Ta}-4.6 \mathrm{Zr}$ & solution-treated + water quenching + UNSM & / & / & $0.00102 \mathrm{~mm}^{3}$ & $0.00014 \mathrm{~mm}^{3}$ & $\begin{array}{c}\text { increased surface hardness }+ \\
\text { nanoscale lamellar } \\
\text { grains }+\alpha \text { precipitates }\end{array}$ & {$[82]$} \\
\hline $\mathrm{Ti}-30 \mathrm{Nb}-4 \mathrm{Sn}$ & laser nitriding & 0.70 & 0.18 & / & / & three-body abrasive wear & [83] \\
\hline Ti-10V-2Fe-3Al & hot-rolled + heat treatment & 0.6 & 0.6 & / & / & oxidation + superelasticity & [74] \\
\hline
\end{tabular}


In addition to the above factors, wear property can be evaluated by wear resistance indices ( $\mathrm{H} / \mathrm{E}$ and $\mathrm{H}^{3} / \mathrm{E}^{2}$ eff). The Ti-Nb-Sn-Cr alloy was designed during adjusting $\mathrm{Sn}$ and $\mathrm{Cr}$. After measurement and calculation, $\mathrm{Ti}-25 \mathrm{Nb}-1 \mathrm{Sn}-2 \mathrm{Cr}$ displayed the highest $\mathrm{H} / \mathrm{E}$ (0.03327) and $\mathrm{H}^{3} / \mathrm{E}^{2}$ eff $(0.00261 \mathrm{GPa})$ [84]. Tong et al. [78] reported the difference in the wear resistance between $\beta$-type Ti-24Nb-38Zr-2Mo and CP Ti. The samples exhibited an excellent wear resistance compared with $\mathrm{CP}$ Ti because of the $\mathrm{Nb} 2 \mathrm{O} 5$ oxide-containing passivation film. Based on that, Majumdar et al. [73] designed Ti-13Zr-13Nb-0.5B and evaluated the wear rate and wear mechanism. The wear rate after furnace cooling and aging treatment was the lowest. The main wear mechanism was microcutting in a dry condition, while the wear mechanism was abrasive wear in the case of bovine serum. Liu et al. [31] developed the hybrid coating on Ti-35Nb-2Ta-3Zr substrate and improved the wear resistance. It involved abrasive wear and adhesive wear by analyzing the friction coefficient and the wear morphology. It is reported [82] that the UNSM treatment on a new $\beta$-type TNTZ alloy resulted in a nanostructure surface layer fabrication. The wear volume of the UNSM-treated $\left(1.02 \times 10^{-3} \mathrm{~mm}^{3}\right)$ sample was more than seven times higher than that of the untreated $\left(0.14 \times 10^{-3} \mathrm{~mm}^{3}\right)$ one.

The issue of poor wear resistance of Ti alloys needs to be solved as soon as possible. At present, the design of alloys based on the chemical composition is a good approach to improve the wear resistance. In addition, several technologies have been developed to prepare a modified layer with high wear resistance. The wear resistance has improved, and the friction coefficient has decreased in the meantime. However, the layers via some modified processes are easy to peel off because of a weak bonding force.

\section{Corrosion Resistance}

Some specific Ti alloys are not good for the human body because of the release of toxic ions [85]. This phenomenon has a negative effect on bone repair and body health. Moreover, the study has proven that TC4 showed toxicity or lead to intoxication after implanting for 3 years [86]. The patient showed sensory-motor axonal neuropathy and hearing loss, which was related to high concentrations of $\mathrm{V}$ in the blood $(6.1 \mu \mathrm{g} / \mathrm{L})$ and urine $(56.0 \mu \mathrm{g} / \mathrm{L})$. Moreover in another study, neurotoxic of aluminum (Al) was demonstrated [87]. Besides, some other elements (such as $\mathrm{Ni}$ and $\mathrm{Cr}$ ) can cause bone resorption, mobility, and breaking. Although TC4 presents excellent corrosion resistance, it is not the best choice for implants.

$\beta$-Ti alloys are widely studied due to their non-cytotoxic nature (without toxic alloying elements) and excellent corrosion resistance [88,89]. However, the applicability of these alloys should be further verified as it is necessary to understand and improve the corrosion resistance of $\beta$-Ti alloys. Surface modification technologies are widely utilized to additionally improve the corrosion resistance of $\beta$-Ti alloys. Usually, the electrolytes are Hank's, Ringer's, and SBF solution in experiments of corrosion resistance. In addition to the modulation of alloys' chemical composition, the common surface treatment involves plasma electrolytic oxidation (PEO), plasma injection, vapor deposition, sputtering, alkali treatment, and other technologies, which can fabricate oxide layers on the alloy surface. The electrochemical behavior of Ti alloys mainly depends on $E_{b}$ and $I_{\text {pass }}$. Thus, higher $E_{b}$, higher $\mathrm{E}_{\mathrm{p}}$, and lower $\mathrm{I}_{\text {pass }}$ in the polarization curves exhibit great corrosion resistance.

It is reported that the corrosion current densities $\left(3-4 \mathrm{nA} / \mathrm{cm}^{2}\right)$ and the film resistances $\left(10^{5} \Omega \cdot \mathrm{cm}^{2}\right)$ of the low-cost Ti-4.7Mo-4.5Fe are close to those of TC4 in Ringer's solution [90]. Great corrosion resistance can be attributed to the stability of the oxide film on the Ti-4.7Mo4.5Fe surface. The Ti-13Nb-13Zr alloy exhibited similar corrosion resistance compared with TC4 because the source of the Ti-13Nb-13Zr and TC4 corrosion resistances is the same; both Ti alloys produced $\mathrm{TiO}_{2}$ film in Hank's solution [91].

Jin et al. [92] fabricated TiNbZrFe alloy via surface mechanical attrition treatment and reached the nanocrystalline size of 10-30 nm. Due to the fabricated stable and dense passive layer on the nanocrystallized surface of the TiNbZrFe alloy, the corrosion resistance improved significantly. 
Prakash et al. [93] studied a new method of surface modification on $\beta$-Ti alloy Ti$35 \mathrm{Nb}-7 \mathrm{Ta}-5 \mathrm{Zr}$ using HA hybrid electrical discharge machining. The method can deposit the biomimetic nanoporous HA layer in situ. The deposited layer was composed of titanium, niobium, tantalum, zirconium, oxygen, calcium, and phosphorus. As shown in Figure 4, the samples treated with the electrical discharge machining (EDM) technique showed superior and higher corrosion resistance than the untreated samples in Ringer's simulated body fluid. Moreover, the HA-deposited bio-ceramic layer indicated excellent corrosion resistance.

Chen et al. [94] successfully developed the PEO coating on the Ti-39Nb-6Zr alloy and studied the electrochemical corrosion and wear behavior of the Ti-39Nb-6Zr alloy before and after modification in PBS solution. The results showed that, after PEO surface treatment, the corrosion and wear resistance of the Ti-39Nb-6Zr alloy in the PBS solution was significantly improved. Wang et al. [95] conducted a systematic study on the MAO treatment of Ti-35Nb-2Ta-3Zr alloy in sodium silicate electrolyte. The results showed that the Ti-35Nb-2Ta-3Zr alloy had good film-forming properties, and a layer of porousstructure-nested film is formed on the surface of Ti-35Nb-2Ta-3Zr alloy. The relative content of the biologically active anatase phase was much higher than that of the rutile phase, which can effectively improve the deposition ability of HA. In addition, since the surface of Ti-35Nb-2Ta-3Zr treated by micro-arc oxidation has a $\mathrm{Nb}_{2} \mathrm{O}_{5}$ phase, an oxide film with the denser and thicker condition is formed, leading to excellent corrosion resistance. Gu et al. [96] also developed Ti-35Nb-2Ta-3Zr alloy by means of surface modification. They used fabricated $\mathrm{TiO}_{2} / \mathrm{Ti}-35 \mathrm{Nb}-2 \mathrm{Ta}-3 \mathrm{Zr}$ anticorrosion micro/nano-composites with different amounts of $\mathrm{TiO}_{2}$ particles via FSP. The refined surface microstructure could increase the compactness of the surface oxide films that eventually affect the corrosion performance. Material with the most $\mathrm{TiO}_{2}$ content has Icorr magnitude five times less than the substrate; hence, the corrosion resistance can be further improved by the $\mathrm{TiO}_{2}$ micro/nano-composite layer. Figure 5 displays the potentiodynamic polarization curves and EIS patterns of the substrate and $\mathrm{TiO}_{2}$ micro/nano-composite layers of Ti-35Nb-2Ta- $3 \mathrm{Zr}$ substrate and FSPed in Hank's solution. Icorr reduced with the increasing amount of $\mathrm{TiO}_{2}$ incorporation at the same rotation speed. The capacitances of the outer and inner layer are less than the substrate, which was attributed to the surface topography and thickness of the passive film.

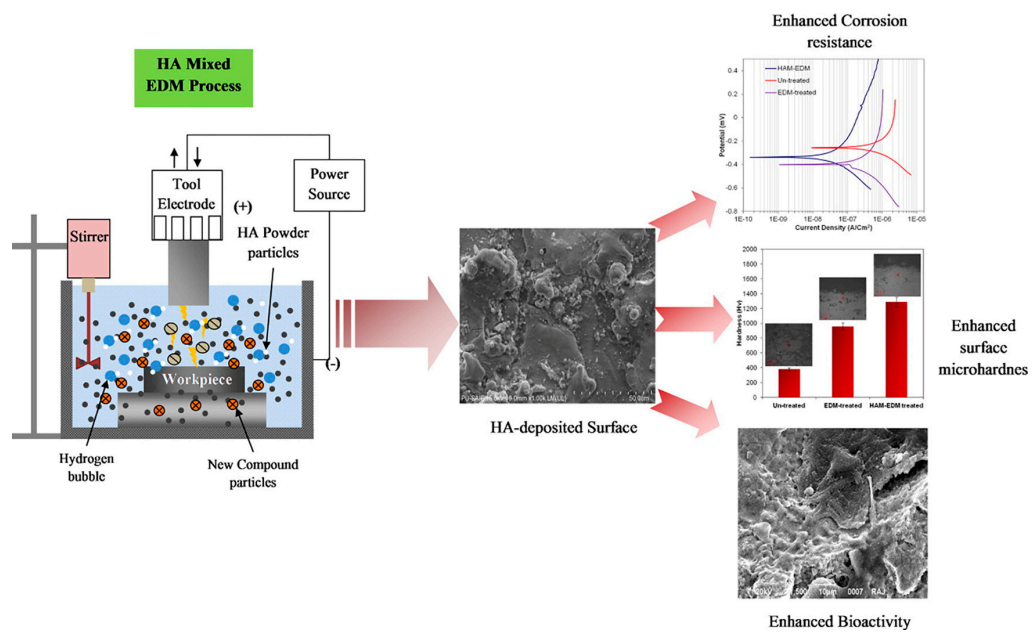

Figure 4. The enhancement of corrosion resistance, hardness, and bioactivity on HA-deposited surface (surface modification of $\beta$-phase Ti implant by hydroaxyapatite mixed electric discharge machining to enhance the corrosion resistance and in-vitro bioactivity). Reproduced with permission from [93], copyright Elsevier, 2017.

Liu et al. [97] proposed a unique method that combined alkali treatment with natural cross-linking agent proanthocyanidin to form a sub-micron porous structure (pore size $100-300 \mathrm{~nm}$ ). The dense inner oxide layer mainly provided enhanced corrosion resistance 
for the Ti2448 alloy stent. Pina et al. [98] found that Ti30Nb4Sn alloys containing Sn have excellent chemical resistance. Bahl et al. [99] studied the tribo-electrochemical behavior of different $\beta$-Ti alloys sintered by powder metallurgy. According to the results, the active and passive dissolution rates increased by attaining the Sn content of $2 \%$ and $4 \%$, leading to enhanced mechanically activated corrosion under the friction corrosion condition.

Diomidis et al. [100] tested the open circuit potential and anodic current of Ti-13Nb13Zr and Ti-29Nb-13Ta-4.6Zr alloys. Ti-13Nb-13Zr and Ti-29Nb-13Ta-4.6Zr showed the ability to restore their passive state during the fretting process. The excellent potential of these $\beta$-Ti alloys to restore their passive state during the fretting process was related to the interaction of the mechanical properties of the passive surface layer and its contact pressure. In addition, they also studied the effect of the bovine serum albumin addition, hyaluronic acid, and triglyceride dipolyphosphate on the fretting corrosion of the Ti-12.5Mo alloy. The results showed that the addition of the sliding film leads to a decrease in the friction coefficient, the elastic adjustment of displacement, and the wear rate of the alloy.

However, the human body environment is very complicated. In addition to electrochemical corrosion, biomedical $\beta$-Ti alloy implants also need to satisfy the friction corrosion conditions. In addition, the material quality, the effect of mechanical force, the chemical composition of the medium, and the alloy itself will affect the $\beta$-Ti alloy. Under such circumstances, the biomedical $\beta$-Ti alloy needs further research on corrosion resistance [85].
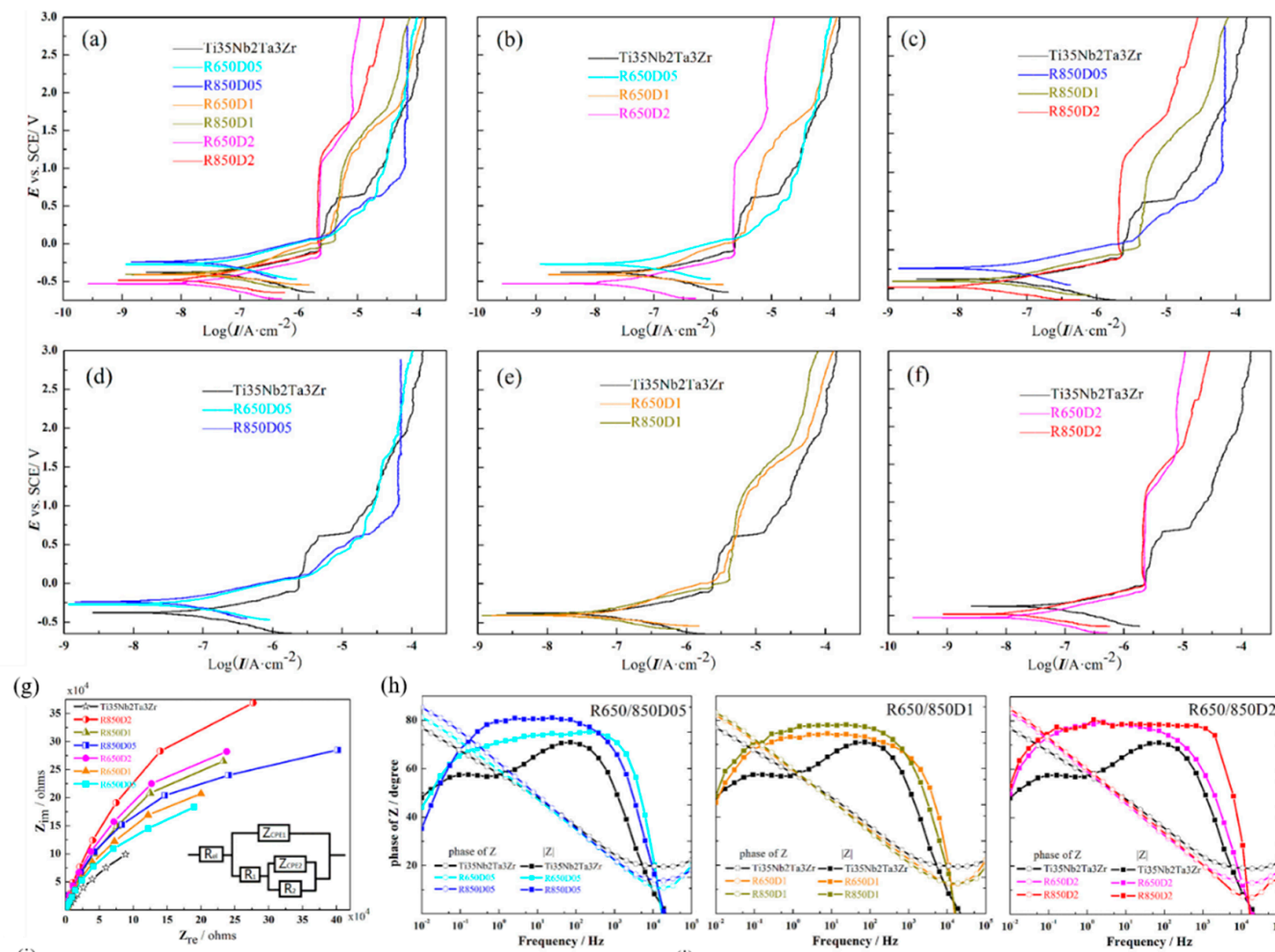

(h)


(i)
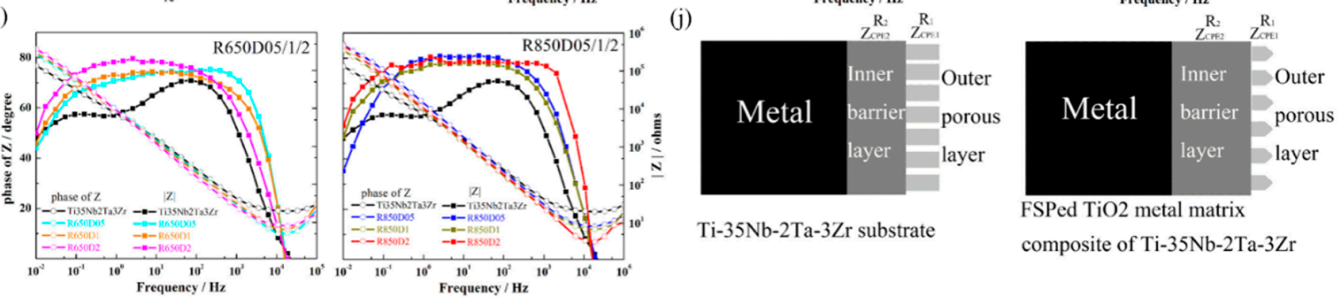

Figure 5. The corrosion behavior of the substrate and $\mathrm{TiO}_{2}$ micro/nano-composite layers in Hank's solution: (a-h) potentiodynamic polarization curves, (g-j) EIS pattern: (g) Nyquist diagram with equivalent circuit, (h) Bode diagrams of $\mathrm{TiO}_{2}$ micro/nano-composite layers at the different rotation speeds, (i) Bode diagrams of $\mathrm{TiO}_{2}$ micro/nano-composite layers at the different amount of $\mathrm{TiO}_{2}$ added, (j) schematic diagrams of the substrate and $\mathrm{TiO}_{2}$ micro/nano-composite layers. Reproduced with permission from [96], copyright Elsevier, 2019. 


\section{Biological Response \\ 6.1. Antibacterial Property}

Antibacterial property refers to the ability of a material to remain effective under the action of bacteria or microorganisms. High antibacterial performance is one of the vital requirements in human implant materials [101]. Bacterial infection has been indicated as one of the main factors in the failure of metallic implants [102]. $\beta$-Ti alloys have been widely used in medical and surgical implants, but they are currently facing the challenge of implant-related infections [83]. Hence, it is crucial to improve the antibacterial property of the $\beta$-Ti alloys.

Chang et al. [103] utilized the fully automated fiber laser system (Micro Laser Systems) for laser nitriding of Ti-30Nb-4Sn in the open air. A set of samples was prepared by varying the duty cycle from $5 \%$ to $100 \%$. In Figure 6, the studied laser-nitrided samples are displayed, including DC5-DC100. The results showed a significant difference in the total bacterial adherence/biofilm formation on the surface coverage of the untreated samples and the laser-nitrided samples. The untreated sample had the highest biofilm coverage of $29.8 \%$, and the total biofilm coverage was significantly decreased and reached 2.9\% (DC60).

a)



BM (untreated)

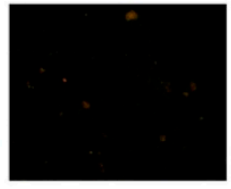

DC5 b)



c)

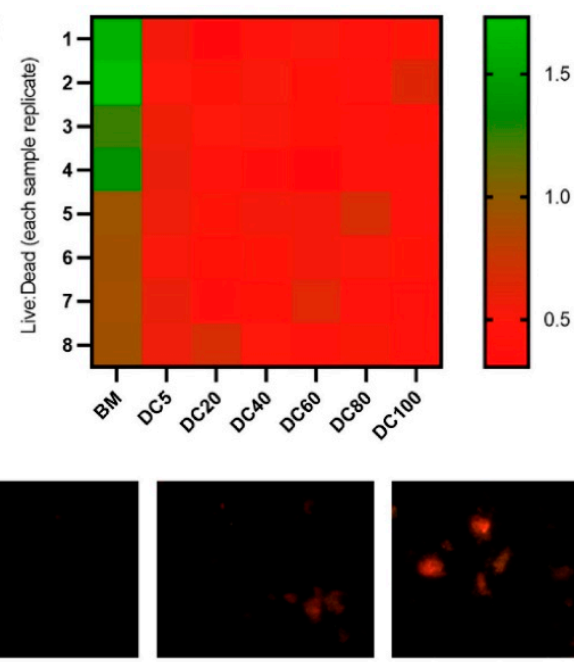

DC60

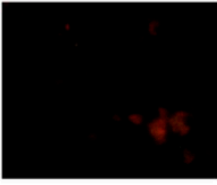

DC80

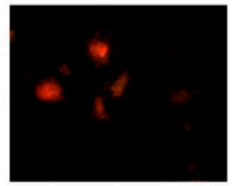

DC100

Figure 6. Bacterial coverage results for the untreated and laser-nitrided surfaces after $24 \mathrm{~h}$ culture with $\mathrm{S}$. aureus. (a) Representative images showing bacterial adherence/biofilm coverage on each sample. Images were obtained by live/dead staining and fluorescence microscopy. Live (viable) bacteria are stained green, and dead (non-viable bacteria) stained red. (b) Percentage biofilm coverage on each treated sample and untreated sample as determined by image analysis ( ${ }^{*}$ denotes significant difference, $\left.{ }^{* *}: p<0.01{ }^{* * *}: p<0.0001\right)$. (c) Ratio of live: dead bacteria on each image analyzed for each sample and untreated sample control and data displayed as a heat-map. The scale shows samples with a greater proportion of live bacteria represented in green and greater proportion of dead bacteria represented in red. Reproduced with permission from [103], copyright Elsevier, 2020.

A laser nitriding treatment was performed on the Ti-35Nb-7Zr-6Ta surface [104]. Biological studies of the laser-nitrided surfaces included in vitro culture for $24 \mathrm{~h}$ using mesenchymal stem cell (MSC) fluorescence staining and Staphylococcus aureus (S. aureus) live/dead staining. The bacteria coverage percentage was decreased from more than $5 \%$ to less than $1 \%$, so it can be claimed that the laser-nitrided surfaces (laser power: $45 \mathrm{~W}$ ) led to a significant antibacterial effect.

Shi et al. [105] fabricated a low elastic modulus Ti-13Nb-13Zr-5Cu alloy with a good antibacterial property (against S. aureus $>90 \%$ ) as the precipitation of the $\mathrm{Ti}_{2} \mathrm{Cu}$ phase. Liu et al. [106] prepared SLA-TiCu by sandblasting and large-grits etching (SLA) to avoid implant-related infection and promote early bone integration. Studies had shown that the antibacterial rate of SLA-TiCu surface increased from $36.6 \%$ to $99.9 \%$ against S. aureus. 
Most $\beta$-Ti alloys do not present an antibacterial property. After being implanted in the human body, the implants are prone to infection, which may cause implant failure, especially in the early stage after implantation, causing pain and an economic burden to the patients. Therefore, it is of great significance to endow the antibacterial property of $\beta$-Ti alloys (incorporation of antibacterial particles) via surface modification.

\subsection{Bone Regeneration}

In recent years, the surface morphology modification effect on the biological activity of titanium implants has been extensively studied. Topography investigations from the bionics perspective revealed that the more similar micro-topography of the implant surface to the human bone structure led to more effectiveness in the biological activity improvement of the implant. More and more shreds of evidence show that the surface microenvironment structure can affect cell growth, which, in turn, affects osseointegration [107]. Micromorphology has been identified as a potential stimulating factor for stem cell osteogenic differentiation and new bone formation. It was reported that $\mathrm{Ti}, \mathrm{Zr}, \mathrm{Nb}$, $\mathrm{Ta}, \mathrm{Au}, \mathrm{Mo}$, and $\mathrm{Sn}$ are highly biocompatible elements [108]. Hence, subsequent surface processing of $\beta$-Ti alloys that includes high biocompatible elements can effectively improve bone regeneration performance. Researchers have proposed various surface modification strategies to produce micron or sub-micron surface topography on titanium implants, such as sandblasting, acid etching, anodizing, spin-coating, sputtering deposition, etc.

Scholars applied some exceptional processes in combination with the characteristics of the alloy itself to directly construct the micro-topography on the surface without introducing other active materials to improve the bone regeneration performance [109-111]. Micro-scale surface topographies can enhance bio-mechanical interlocking and increase bone-anchoring. Kheradmandfard et al. [68] fabricated a gradient nanostructure layer on the TNTZ surface by UNSM technology. The microstructure of the top surface layer was composed of nanoflakes with a width of $60-200 \mathrm{~nm}$. The results showed that the nanostructured titanium surface induced enhanced cell adhesion, osteoblast differentiation, and improved osseointegration toward mesenchymal stem cells. The micro-pattern will assist the TNTZ implants in attaining high biological activity and bone regeneration performance.

$\mathrm{Li}$ et al. [112] prepared hierarchical nanostructures on the surface of Ti-24Nb-4Zr-7.9Sn alloy through anodic oxidation, forming a nanoscale bone-like structure and nanotubes. They observed the behavior of bone marrow stromal cells on the surface of the sample through in vitro culture. They also conducted histological analysis after implanting the modified materials in vivo to evaluate the biocompatibility and osseointegration of the implant surface. The results showed a generation of a hierarchical structure with nano-scale bone-like layers on the surface of Ti-24Nb-4Zr-7.9Sn. The BIC value was $65.48 \pm 8.0 \%$ compared with $33.21 \pm 6.05 \%$ of untreated specimen, and the bone area reached $55.28 \pm 14.92 \%$ compared with $20.64 \pm 10.28 \%$ of untreated. The Ti-24Nb-4Zr-7.9Sn surface showed high biocompatibility with bone marrow mesenchymal stem cells in vitro and osseointegration in vivo.

Fu et al. [113] found that the behavior of murine mesenchymal stem cells (MSCs) and murine preosteoblastic cells (MC3T3-E1) is regulated by the cell-material interface. They used selective laser melting and alkaline heat treatment techniques on titanium implants and constructed ordered-micro and disordered-nano patterned structures. Compared with untreated specimens, the expression level of osteogenic genes in the treated implants increased by 3.43 times. The optimal bone formation structure had a steady wave structure (horizontal direction: ridge, $2.7 \mu \mathrm{m}$; grooves, $5.3 \mu \mathrm{m}$; and vertical direction: distance, $700 \mu \mathrm{m})$ with the appropriate density of nano-branches $\left(6.0\right.$ per $\left.\mu \mathrm{m}^{2}\right)$. Ordered grooves provided direction guidance for cells, and disordered branches influenced the shape of cells by maintaining nanostructures with different spacing and densities. Micro-nano patterned structures can provide biophysical clues to guide the development of cell phenotypes, including cell size, shape, and direction, thereby affecting cell survival, growth, and differentiation processes. Therefore, the superimposed isotropic and anisotropic cues, 
ordered-micro and disordered-nano patterned structures, can promote integrin $\alpha 5$, integrin $\beta 1$, cadherin 2 , Runx2, and Opn by activating Wnt/ $\beta$-catenin signaling and Ocn, thereby further transferring and changing the cell shape and inducing nuclear orientation (as shown in Figure 7). The osteogenic differentiation induced by the ordered-micro and disordered-nano pattern structure is related to $\mathrm{Wnt} / \beta$-catenin signaling and was further proved by the common Wnt signaling inhibitor Dickkopf1. Ordered micro-topography and disordered nano-topography pattern structures can lead to osteogenic differentiation in vitro and bone regeneration in vivo.

The osseointegration ability of $\beta$-Ti alloys increases in comparison to the material before modification, which is essential for implants. The surface microenvironment structure plays an important role in cell growth, which, in turn, affects osseointegration. Many modified methods, including sandblasting, anodizing, and so on, can provide microstructure and even nanostructure. Additionally, the osseointegration behaviors of $\beta$-Ti alloys increase in comparison to the material before modification, which is essential for implants. There is a trend of constructing the micro-topography directly on the alloy surface without introducing other active materials. Furthermore, the principle of the complex microstructure improving bone regeneration requires further study.



Figure 7. Schematic illustration of patterned Ti for osteogenic differentiation. Function 1: Activation of integrin $\alpha 5 \beta 1$ heterodimers and regulation of cell morphology. Function 2: Stimulation of MSCs and MC3T3-E1-related gene and $\beta$-catenin expressions to promote osteogenic differentiation. Reproduced with permission from [113], copyright Elsevier, 2020.

\section{Shortcomings and Prospects}

$\beta$-Ti alloys show notable potential in orthopedic and dental applications, mainly as low modulus and low or non-toxic elements. However, low wear resistance is a challenge for $\beta$-Ti alloys, which causes abrasive particles running in the body fluid environment. Additionally, corrosion behavior may lead to infection and implant failure. Besides, despite excellent biocompatibility, antibacterial ability and bone regeneration are also necessary with $\beta$-Ti alloys for bone recovery. Researchers have studied and developed various novel $\beta$-Ti alloys, but there is a lack of systematic optimization. The traditional methods of selecting chemical compositions have high time costs. This results in most of the $\beta$-Ti alloys still being in the fundamental research stage rather than clinical surgery. Thus, a general standard is necessary to be formulated. Moreover, the relationship of hardness, friction behavior, and corrosion resistance is not clarified yet. It seems that the new strategy may be to explain the relationship between these characteristics by computer simulation. The single and comprehensive model of the simulated environment needs to be designed to reduce unnecessary animal experiments in vivo. In short, $\beta$-Ti alloys present considerable prospects in the future for orthopedic and dental applications. 


\section{Conclusions}

The performance of the $\beta$-Ti alloy consists of more adaptation to the required demands of biomedical materials compared to other alloys, but it is still far from the requirements of biomedical materials. It is necessary to develop novel targeted $\beta$-Ti alloys rapidly. The computer simulation to search for and optimize the composition of Ti alloys may be a suitable approach to solve the issue. The utilization of surface modification techniques can improve the mechanical properties, wear resistance, corrosion resistance, and biological responses of $\beta$-Ti alloys. However, the specific relationship between these aspects is complicated and needs to be clarified by considering the deeper mechanisms rather than just adjusting the parameters during the processes. The improvements of $\beta$-Ti alloys deserve continuous attention. The successful development of $\beta$-Ti alloys is beneficial for clinical surgery in the orthopedic and dental fields.

Author Contributions: Conceptualization, J.L. and Y.T.; investigation, Q.W.; resources, J.L. and Y.T.; data curation, Q.W.; writing-original draft preparation, L.S., Y.D. and K.D.; writing-review and editing, Q.W.; visualization, L.W.; supervision, H.W. and L.W.; project administration, L.W. All authors have read and agreed to the published version of the manuscript.

Funding: The authors would like to acknowledge the financial supports of National Natural Science Foundation under (Grant No.51674167,51831011 and 5191101889), Shanghai Science and Technology Project: 20S31900100 Medical Engineering Cross Research Foundation of Shanghai Jiao Tong University (Grant No. YG2021QN61). The authors would like to acknowledge the institutes of Guangxi Key Laboratory of basic and translational research of Bone and Joint Degenerative Diseases, and Guangxi Biomedical Materials and Engineering Research Center for Bone and Joint Degenerative Diseases.

Institutional Review Board Statement: Not applicable.

Informed Consent Statement: Not applicable.

Data Availability Statement: Not applicable.

Acknowledgments: The authors sincerely thank Shokouh Attarilar for language polishing of this paper.

Conflicts of Interest: The authors declare no conflict of interest.

\section{References}

1. Zhang, L.C.; Chen, L.Y. A Review on Biomedical Titanium Alloys: Recent Progress and Prospect. Adv. Eng. Mater. 2019, 21, 1801215. [CrossRef]

2. Raji, S.A.; Popoola AP, I.; Pityana, S.L.; Popoola, O.M. Characteristic effects of alloying elements on $\hat{\mathrm{I}}^{2}$ solidifying titanium aluminides: A review. Heliyon 2020, 6, e04463. [CrossRef]

3. Rossi, M.C.; Amado, J.M.; Tobar, M.J.; Vicente, A.; Yañez, A.; Amigó, V. Effect of alloying elements on laser surface modification of powder metallurgy to improve surface mechanical properties of beta titanium alloys for biomedical application. J. Mater. Res. Technol. 2021, 14, 1222-1234. [CrossRef]

4. Pitchi, C.S.; Priyadarshini, A.; Sana, G.; Narala, S.K.R. A review on alloy composition and synthesis of $\beta$-Titanium alloys for biomedical applications. Mater. Today Proc. 2020, 26, 3297-3304. [CrossRef]

5. Goldberg, J. An Evaluation of Beta Titanium Alloys for Use in Orthodontic Appliances. J. Dent. Res. 1979, 58, 593-599. [CrossRef]

6. Liu, S.; Liu, W.; Liu, J.; Liu, J.; Zhang, L.; Tang, Y.; Zhang, L.-C.; Wang, L. Compressive properties and microstructure evolution in NiTiNb alloy with mesh eutectic phase. Mater. Sci. Eng. A 2021, 801, 140434. [CrossRef]

7. Geetha, M.; Singh, A.K.; Asokamani, R.; Gogia, A.K. Ti based biomaterials, the ultimate choice for orthopaedic implants-A review. Prog. Mater. Sci. 2009, 54, 397-425. [CrossRef]

8. Bolzoni, L.; Ruiz-Navas, E.M.; Gordo, E. Investigation of the factors influencing the tensile behaviour of PM Ti-3Al-2.5V alloy. Mater. Sci. Eng. A 2014, 609, 266-272. [CrossRef]

9. Semlitsch, M.F.; Weber, H.; Streicher, R.M.; Schön, R. Joint replacement components made of hot-forged and surface-treated Ti-6Al-7Nb alloy. Biomaterials 1992, 13, 781-788. [CrossRef]

10. He, G.; Liu, H.; Tan, Q.; Ni, J. Diffusion bonding of Ti-2.5Al-2.5Mo-2.5Zr and Co-Cr-Mo alloys. J. Alloys Compd. 2011, 509, 7324-7329. [CrossRef]

11. Kwon, Y.M.; An, S.; Yeo, I.; Tirumala, V.; Chen, W.; Klemt, C. Radiographic Risk Factors Associated With Adverse Local Tissue Reaction in Head-Neck Taper Corrosion of Primary Metal-on-Polyethylene Total Hip Arthroplasty. J. Am. Acad. Orthop. Surg. 2021, 29, 353-360. [CrossRef] 
12. Sak, A.; Moskalewicz, T.; Zimowski, S.; Cieniek, L.; Dubiel, B.; Radziszewska, A.; Kot, M.; Lukaszczyk, A. Influence of polyetheretherketone coatings on the Ti-13Nb-13Zr titanium alloy's bio-tribological properties and corrosion resistance. Mater. Sci. Eng. C Mater. Biol. Appl. 2016, 63, 52-61. [CrossRef]

13. Liu, Y.J.; Li, S.J.; Wang, H.L.; Hou, W.T.; Hao, Y.L.; Yang, R.; Sercombe, T.B.; Zhang, L.C. Microstructure, defects and mechanical behavior of beta-type titanium porous structures manufactured by electron beam melting and selective laser melting. Acta Mater. 2016, 113, 56-67. [CrossRef]

14. Liu, Y.; Li, S.; Hou, W.; Wang, S.; Hao, Y.; Yang, R.; Sercombe, T.B.; Zhang, L.-C. Electron Beam Melted Beta-type Ti-24Nb-4Zr-8Sn Porous Structures With High Strength-to-Modulus Ratio. J. Mater. Sci. Technol. 2016, 32, 505-508. [CrossRef]

15. Ho, W.F.; Ju, C.P.; Chern Lin, J.H. Structure and properties of cast binary Ti-Mo alloys. Biomaterials 1999, 20, 2115-2122. [CrossRef]

16. Zha, S. Study on the Microstructure and Property of New $\beta$-Ti28Nb24.5Zr Alloy for Biomedic Applications. Master's Thesis, Tianjin University, Tianjin, China, 2006.

17. Zhu, C.; Lv, Y.; Qian, C.; Ding, Z.; Jiao, T.; Gu, X.; Lu, E.; Wang, L.; Zhang, F. Microstructures, mechanical, and biological properties of a novel Ti-6V-4V/zinc surface nanocomposite prepared by friction stir processing. Int. J. Nanomed. 2018, 13, 1881. [CrossRef]

18. Wang, L.; Xie, L.; Lv, Y.; Zhang, L.-C.; Chen, L.; Meng, Q.; Qu, J.; Zhang, D.; Lu, W. Microstructure evolution and superelastic behavior in Ti-35Nb-2Ta-3Zr alloy processed by friction stir processing. Acta Mater. 2017, 131, 499-510. [CrossRef]

19. Hafeez, N.; Liu, J.; Wang, L.; Wei, D.; Tang, Y.; Lu, W.; Zhang, L.-C. Superelastic response of low-modulus porous beta-type Ti-35Nb-2Ta-3Zr alloy fabricated by laser powder bed fusion. Addit. Manuf. 2020, 34, 101264. [CrossRef]

20. Raza, D.; Kumar, G.; Uzair, M.; Singh, M.K.; Sultan, D.; Kumar, R. Development and heat treatment of $\beta$-phase titanium alloy for orthopedic application. Mater. Today Proc. 2021. [CrossRef]

21. Karre, R.; Dey, S.R. Progress in Development of Beta Titanium Alloys for Biomedical Applications. In Encyclopedia of Smart Materials; Elsevier: Amsterdam, The Netherlands, 2019; Volume 5, pp. 512-527. [CrossRef]

22. Liu, S.; Liu, J.; Wang, L.; Ma, R.L.W.; Zhong, Y.; Lu, W.; Zhang, L.C. Superelastic behavior of in-situ eutectic-reaction manufactured high strength 3D porous NiTi-Nb scaffold. Scr. Mater. 2020, 181, 121-126.

23. Xie, K.Y.; Wang, Y.; Zhao, Y.; Chang, L.; Wang, G.; Chen, Z.; Cao, Y.; Liao, X.; Lavernia, E.J.; Valiev, R.Z.; et al. Nanocrystalline beta-Ti alloy with high hardness, low Young's modulus and excellent in vitro biocompatibility for biomedical applications. Mater Sci. Eng. C Mater. Biol. Appl. 2013, 33, 3530-3536. [CrossRef]

24. Singleton, R.C.; Pharr, G.M.; Nyman, J.S. Increased tissue-level storage modulus and hardness with age in male cortical bone and its association with decreased fracture toughness. Bone 2021, 148, 115949. [CrossRef]

25. Callioglu, S.; Acar, P. Design of beta-Titanium microstructures for implant materials. Mater. Sci. Eng. C Mater. Biol. Appl. 2020, 110, 110715. [CrossRef] [PubMed]

26. Dearnley, P.A.; Dahm, K.L.; Çimenoğlu, H. The corrosion-wear behaviour of thermally oxidised CP-Ti and Ti-6Al-4V. Wear 2004, 256, 469-479. [CrossRef]

27. Niinomi, M.; Kuroda, D.; Fukunaga, K.-I.; Morinaga, M.; Kato, Y.; Yashiro, T.; Suzuki, A. Corrosion wear fracture of new $\beta$ type biomedical titanium alloys. Mater. Sci. Eng. A 1999, 263, 193-199. [CrossRef]

28. Kaur, S.; Ghadirinejad, K.; Oskouei, R.H. An Overview on the Tribological Performance of Titanium Alloys with Surface Modifications for Biomedical Applications. Lubricants 2019, 7, 65. [CrossRef]

29. Bahl, S.; Suwas, S.; Chatterjee, K. Comprehensive review on alloy design, processing, and performance of $\beta$ Titanium alloys as biomedical materials. Int. Mater. Rev. 2020, 66, 114-139. [CrossRef]

30. Torrento, J.E.; Grandini, C.R.; Sousa, T.S.P.; Rocha, L.A.; Gonçalves, T.M.; Sottovia, L.; Rangel, E.C.; Cruz, N.C.; Correa, D.R.N. Bulk and surface design of MAO-treated Ti-15Zr-15Mo-Ag alloys for potential use as biofunctional implants. Mater. Lett. 2020, 269, 127661. [CrossRef]

31. Liu, S.; Wang, Q.; Liu, W.; Tang, Y.; Liu, J.; Zhang, H.; Liu, X.; Liu, J.; Yang, J.; Zhang, L.C.; et al. Multi-scale hybrid modified coatings on titanium implants for non-cytotoxicity and antibacterial properties. Nanoscale 2021, 13, 10587-10599. [CrossRef] [PubMed]

32. Kandavalli, S.R.; Wang, Q.; Ebrahimi, M.; Gode, C.; Djavanroodi, F.; Attarilar, S.; Liu, S. A Brief Review on the Evolution of Metallic Dental Implants: History, Design, and Application. Front. Mater. 2021, 8, 140. [CrossRef]

33. Attarilar, S.; Yang, J.; Ebrahimi, M.; Wang, Q.; Liu, J.; Tang, Y.; Yang, J. The Toxicity Phenomenon and the Related Occurrence in Metal and Metal Oxide Nanoparticles: A Brief Review From the Biomedical Perspective. Front. Bioeng. Biotechnol. $2020,8,822$. [CrossRef]

34. Çaha, I.; Alves, A.C.; Rocha, L.A.; Toptan, F. A Review on Bio-functionalization of $\beta$-Ti Alloys. J. Bio-Tribo-Corros. 2020, 6, 1-31. [CrossRef]

35. Wang, Q.; Zhou, P.; Liu, S.; Attarilar, S.; Ma, R.L.; Zhong, Y.; Wang, L. Multi-Scale Surface Treatments of Titanium Implants for Rapid Osseointegration: A Review. Nanomater 2020, 10, 1244. [CrossRef]

36. Wang, Q.; Wu, L.; Liu, S.; Cao, P.; Yang, J.; Wang, L. Nanostructured Titanium Alloys Surface Modification Technology for Antibacterial and Osteogenic Properties. Curr. Nanosci. 2021, 17, 175-193. [CrossRef]

37. Zhang, L.-C.; Chen, L.-Y.; Wang, L. Surface Modification of Titanium and Titanium Alloys: Technologies, Developments, and Future Interests. Adv. Eng. Mater. 2020, 22, 1901258. [CrossRef]

38. Kurup, A.; Dhatrak, P.; Khasnis, N. Surface modification techniques of titanium and titanium alloys for biomedical dental applications: A review. Mater. Today Proc. 2021, 39, 84-90. [CrossRef] 
39. Liang, S. Review of the Design of Titanium Alloys with Low Elastic Modulus as Implant Materials. Adv. Eng. Mater. $2020,22,2000555$. [CrossRef]

40. Okulov, I.V.; Okulov, A.V.; Soldatov, I.V.; Luthringer, B.; Willumeit-Romer, R.; Wada, T.; Kato, H.; Weissmuller, J.; Markmann, J. Open porous dealloying-based biomaterials as a novel biomaterial platform. Mater. Sci. Eng. C Mater. Biol. Appl. 2018, 88, 95-103. [CrossRef] [PubMed]

41. Luthringer, B.J.; Ali, F.; Akaichi, H.; Feyerabend, F.; Ebel, T.; Willumeit, R. Production, characterisation, and cytocompatibility of porous titanium-based particulate scaffolds. J. Mater. Sci. Mater. Med. 2013, 24, 2337-2358. [CrossRef] [PubMed]

42. Prashanth, K.; Zhuravleva, K.; Okulov, I.; Calin, M.; Eckert, J.; Gebert, A. Mechanical and Corrosion Behavior of New Generation Ti-45Nb Porous Alloys Implant Devices. Technologies 2016, 4, 33. [CrossRef]

43. Okulov, I.V.; Weissmuller, J.; Markmann, J. Dealloying-based interpenetrating-phase nanocomposites matching the elastic behavior of human bone. Sci. Rep. 2017, 7, 20. [CrossRef]

44. Okulov, A.V.; Volegov, A.S.; Weissmüller, J.; Markmann, J.; Okulov, I.V. Dealloying-based metal-polymer composites for biomedical applications. Scr. Mater. 2018, 146, 290-294. [CrossRef]

45. Liu, J.; Tang, Y.; Liu, J.; Wang, L. Research progress in titanium alloy in the field of orthopaedic implants. J. Mater. Eng. 2021, 49, 11-15.

46. Okulov, I.V.; Okulov, A.V.; Volegov, A.S.; Markmann, J. Tuning microstructure and mechanical properties of open porous TiNb and TiFe alloys by optimization of dealloying parameters. Scr. Mater. 2018, 154, 68-72. [CrossRef]

47. Berger, S.A.; Okulov, I.V. Open Porous $\alpha+\beta$ Titanium Alloy by Liquid Metal Dealloying for Biomedical Applications. Metals 2020, 10, 1450. [CrossRef]

48. Li, P.; Zhang, H.; Tong, T.; He, Z. The rapidly solidified $\beta$-type Ti-Fe-Sn alloys with high specific strength and low elastic modulus. J. Alloys Compd. 2019, 786, 986-994. [CrossRef]

49. Xu, Y.; Gao, J.; Huang, Y.; Rainforth, W.M. A low-cost metastable beta Ti alloy with high elastic admissible strain and enhanced ductility for orthopaedic application. J. Alloys Compd. 2020, 835, 155391. [CrossRef]

50. Li, P.; Ma, X.; Tong, T.; Wang, Y. Microstructural and mechanical properties of $\beta$-type Ti-Mo-Nb biomedical alloys with low elastic modulus. J. Alloys Compd. 2020, 815, 152412. [CrossRef]

51. Guo, X.; Zhang, C.; Tian, Q.; Yu, D. Liquid metals dealloying as a general approach for the selective extraction of metals and the fabrication of nanoporous metals: A review. Mater. Today Commun. 2021, 26, 102007. [CrossRef]

52. Okulov, I.V.; Joo, S.H.; Okulov, A.V.; Volegov, A.S.; Luthringer, B.; Willumeit-Romer, R.; Zhang, L.; Madler, L.; Eckert, J.; Kato, H. Surface Functionalization of Biomedical Ti-6Al-7Nb Alloy by Liquid Metal Dealloying. Nanomater 2020, 10, 1479. [CrossRef]

53. Okulov, I.V.; Wilmers, J.; Joo, S.-H.; Bargmann, S.; Kim, H.S.; Kato, H. Anomalous compliance of interpenetrating-phase composite of Ti and Mg synthesized by liquid metal dealloying. Scr. Mater. 2021, 194, 113660. [CrossRef]

54. Zhu, Y.; Wang, X.; Wang, L.; Fu, Y.; Qin, J.; Lu, W.; Zhang, D. Influence of forging deformation and heat treatment on microstructure of Ti-xNb-3Zr-2Ta alloys. Mater. Sci. Eng. C 2012, 32, 126-132. [CrossRef]

55. Zhang, T.; Liu, C.-T. Design of titanium alloys by additive manufacturing: A critical review. Adv. Powder Mater. 2021. [CrossRef]

56. Wang, L.; Qu, J.; Chen, L.; Meng, Q.; Zhang, L.-C.; Qin, J.; Zhang, D.; Lu, W. Investigation of Deformation Mechanisms in $\beta$-Type Ti-35Nb-2Ta-3Zr Alloy via FSP Leading to Surface Strengthening. Metall. Mater. Trans. A 2015, 46, 4813-4818. [CrossRef]

57. Niinomi, M. Fatigue performance and cyto-toxicity of low rigidity titanium alloy, Ti-29Nb-13Ta-4.6Zr. Biomaterials 2003, 24, 2673-2683. [CrossRef]

58. Zhang, T.; Fan, Q.; Ma, X.; Wang, W.; Wang, K.; Shen, P.; Yang, J.; Wang, L. Effect of laser remelting on microstructural evolution and mechanical properties of Ti-35Nb-2Ta-3Zr alloy. Mater. Lett. 2019, 253, 310-313. [CrossRef]

59. Lin, Z.; Wang, L.; Xue, X.; Lu, W.; Qin, J.; Zhang, D. Microstructure evolution and mechanical properties of a Ti-35Nb-3Zr-2Ta biomedical alloy processed by equal channel angular pressing (ECAP). Mater. Sci. Eng. C Mater. Biol. Appl. 2013, 33, $4551-4561$. [CrossRef]

60. Liu, R.; Yuan, S.; Lin, N.; Zeng, Q.; Wang, Z.; Wu, Y. Application of ultrasonic nanocrystal surface modification (UNSM) technique for surface strengthening of titanium and titanium alloys: A mini review. J. Mater. Res. Technol. 2021, 11, 351-377. [CrossRef]

61. Wang, L.; Wang, Y.; Huang, W.; Liu, J.; Tang, Y.; Zhang, L.; Fu, Y.; Zhang, L.-C.; Lu, W. Tensile and superelastic behaviors of Ti-35Nb-2Ta-3Zr with gradient structure. Mater. Des. 2020, 194, 108961. [CrossRef]

62. Niinomi, M.; Nakai, M. Titanium-Based Biomaterials for Preventing Stress Shielding between Implant Devices and Bone. Int. J. Biomater. 2011, 2011, 836587. [CrossRef]

63. Kuroda, D.; Niinomi, M.; Morinaga, M.; Kato, Y.; Yashiro, T. Design and mechanical properties of new $\beta$ type titanium alloys for implant materials. Mater. Sci. Eng. A 1998, 243, 244-249. [CrossRef]

64. Niinomi, M.; Nakai, M.; Hieda, J. Development of new metallic alloys for biomedical applications. Acta Biomater. 2012, 8, 3888-3903. [CrossRef] [PubMed]

65. Lee, Y.-S.; Niinomi, M.; Nakai, M.; Narita, K.; Cho, K.; Liu, H. Wear transition of solid-solution-strengthened Ti-29Nb-13Ta-4.6Zr alloys by interstitial oxygen for biomedical applications. J. Mech. Behav. Biomed. Mater. 2015, 51, 398-408. [CrossRef]

66. Makuch, N.; Kulka, M.; Dziarski, P.; Przestacki, D. Laser surface alloying of commercially pure titanium with boron and carbon. Opt. Lasers Eng. 2014, 57, 64-81. [CrossRef]

67. Gao, Q.; Yan, H.; Qin, Y.; Zhang, P.; Guo, J.; Chen, Z.; Yu, Z. Laser cladding Ti-Ni/TiN/TiW+TiS/WS2 self-lubricating wear resistant composite coating on Ti-6Al-4V alloy. Opt. Laser Technol. 2019, 113, 182-191. [CrossRef] 
68. Kheradmandfard, M.; Kashani-Bozorg, S.F.; Kim, C.L.; Hanzaki, A.Z.; Pyoun, Y.S.; Kim, J.H.; Amanov, A.; Kim, D.E. Nanostructured beta-type titanium alloy fabricated by ultrasonic nanocrystal surface modification. Ultrason. Sonochem. 2017, 39, 698-706. [CrossRef] [PubMed]

69. Chauhan, A.S.; Jha, J.S.; Telrandhe, S.; Srinivas, V.; Gokhale, A.A.; Mishra, S.K. Laser surface treatment of $\alpha-\beta$ titanium alloy to develop a $\beta$-rich phase with very high hardness. J. Mater. Process. Technol. 2021, 288, 116873. [CrossRef]

70. Molinari, A.; Straffelini, G.; Tesi, B.; Bacci, T. Dry sliding wear mechanisms of the Ti6Al4V alloy. Wear 1997, 208, 105-112. [CrossRef]

71. Cui, W.-F.; Niu, F.-J.; Tan, Y.-L.; Qin, G.-W. Microstructure and tribocorrosion performance of nanocrystalline TiN graded coating on biomedical titanium alloy. Trans. Nonferrous Met. Soc. China 2019, 29, 1026-1035. [CrossRef]

72. Graves, A.; Norgren, S.; Wan, W.; Singh, S.; Kritikos, M.; Xiao, C.; Crawforth, P.; Jackson, M. On the mechanism of crater wear in a high strength metastable $\beta$ titanium alloy. Wear 2021, 484, 203998. [CrossRef]

73. Majumdar, P.; Singh, S.B.; Chakraborty, M. Wear properties of Ti-13Zr-13Nb (wt.\%) near $\beta$ titanium alloy containing $0.5 w t . \%$ boron in dry condition, Hank's solution and bovine serum. Mater. Sci. Eng. C 2010, 30, 1065-1075. [CrossRef]

74. Mehdi, M.; Farokhzadeh, K.; Edrisy, A. Dry sliding wear behavior of superelastic Ti-10V-2Fe-3Al $\beta$-titanium alloy. Wear 2016, 350, 10-20. [CrossRef]

75. Weng, Z.; Gu, K.; Cui, C.; Cai, H.; Liu, X.; Wang, J. Microstructure evolution and wear behavior of titanium alloy under cryogenic dry sliding wear condition. Mater. Charact. 2020, 165, 110385. [CrossRef]

76. Li, X.X.; Zhou, Y.; Ji, X.L.; Li, Y.X.; Wang, S.Q. Effects of sliding velocity on tribo-oxides and wear behavior of Ti-6Al-4V alloy. Tribol. Int. 2015, 91, 228-234. [CrossRef]

77. Huang, C.; Zhang, Y.; Vilar, R.; Shen, J. Dry sliding wear behavior of laser clad TiVCrAlSi high entropy alloy coatings on Ti-6Al-4V substrate. Mater. Des. 2012, 41, 338-343. [CrossRef]

78. Tong, X.; Sun, Q.; Zhang, D.; Wang, K.; Dai, Y.; Shi, Z.; Li, Y.; Dargusch, M.; Huang, S.; Ma, J.; et al. Impact of scandium on mechanical properties, corrosion behavior, friction and wear performance, and cytotoxicity of a beta-type Ti-24Nb-38Zr-2Mo alloy for orthopedic applications. Acta Biomater. 2021, 134, 791-803. [CrossRef] [PubMed]

79. Nakai, M.; Iwasaki, T.; Ueki, K. Differences in the effect of surface texturing on the wear loss of $\beta$-type Ti-Nb-Ta-Zr and $(\alpha+\beta)$-type Ti-6Al-4V ELI alloys in contact with zirconia in physiological saline solution. J. Mech. Behav. Biomed. Mater. 2021, 124, 104808. [CrossRef]

80. Jiang, X.; Dai, Y.; Xiang, Q.; Liu, J.; Yang, F.; Zhang, D. Microstructure and wear behavior of inductive nitriding layer in Ti-25Nb-3Zr-2Sn-3Mo alloys. Surf. Coat. Technol. 2021, 427, 127835. [CrossRef]

81. Hua, K.; Zhang, Y.; Zhang, F.; Kou, H.; Li, X.; Wu, H.; Wang, H. Microstructure refinement and enhanced wear-resistance modulated by stress relaxation processing in a metastable $\beta$ titanium alloy. Mater. Charact. 2021, 181, 111505. [CrossRef]

82. Kheradmandfard, M.; Kashani-Bozorg, S.F.; Lee, J.S.; Kim, C.-L.; Hanzaki, A.Z.; Pyun, Y.-S.; Cho, S.-W.; Amanov, A.; Kim, D.-E. Significant improvement in cell adhesion and wear resistance of biomedical $\beta$-type titanium alloy through ultrasonic nanocrystal surface modification. J. Alloys Compd. 2018, 762, 941-949. [CrossRef]

83. Zhang, Y.; Chu, K.; He, S.; Wang, B.; Zhu, W.; Ren, F. Fabrication of high strength, antibacterial and biocompatible Ti-5Mo-5Ag alloy for medical and surgical implant applications. Mater. Sci. Eng. C Mater. Biol. Appl. 2020, 106, 110165. [CrossRef] [PubMed]

84. Jawed, S.F.; Rabadia, C.D.; Liu, Y.J.; Wang, L.Q.; Li, Y.H.; Zhang, X.H.; Zhang, L.C. Mechanical characterization and deformation behavior of $\beta$-stabilized Ti-Nb-Sn-Cr alloys. J. Alloys Compd. 2019, 792, 684-693. [CrossRef]

85. Dias Corpa Tardelli, J.; Bolfarini, C.; Candido Dos Reis, A. Comparative analysis of corrosion resistance between beta titanium and Ti-6Al-4V alloys: A systematic review. J. Trace Elem. Med. Biol. 2020, 62, 126618. [CrossRef] [PubMed]

86. Moretti, B.; Pesce, V.; Maccagnano, G.; Vicenti, G.; Lovreglio, P.; Soleo, L.; Apostoli, P. Peripheral neuropathy after hip replacement failure: Is vanadium the culprit? Lancet 2012, 379, 1676. [CrossRef]

87. Mirza, A.; King, A.; Troakes, C.; Exley, C. Aluminium in brain tissue in familial Alzheimer's disease. J. Trace Elem. Med. Biol. 2017, 40, 30-36. [CrossRef]

88. Bansal, P.; Singh, G.; Sidhu, H.S. Improvement of surface properties and corrosion resistance of Ti13Nb13Zr titanium alloy by plasma-sprayed HA/ZnO coatings for biomedical applications. Mater. Chem. Phys. 2021, 257, 123738. [CrossRef]

89. Vlcak, P.; Fojt, J.; Koller, J.; Drahokoupil, J.; Smola, V. Surface pre-treatments of Ti-Nb-Zr-Ta beta titanium alloy: The effect of chemical, electrochemical and ion sputter etching on morphology, residual stress, corrosion stability and the MG-63 cell response. Results Phys. 2021, 28, 104613. [CrossRef]

90. Abd-elrhman, Y.; Gepreel, M.A.H.; Abdel-Moniem, A.; Kobayashi, S. Compatibility assessment of new V-free low-cost Ti-4.7Mo4.5Fe alloy for some biomedical applications. Mater. Des. 2016, 97, 445-453. [CrossRef]

91. Assis, S.L.D.; Wolynec, S.; Costa, I. Corrosion characterization of titanium alloys by electrochemical techniques. Electrochim. Acta 2006, 51, 1815-1819. [CrossRef]

92. Jin, L.; Cui, W.-F.; Song, X.; Liu, G.; Zhou, L. Effects of surface nanocrystallization on corrosion resistance of $\beta$-type titanium alloy. Trans. Nonferrous Met. Soc. China 2014, 24, 2529-2535. [CrossRef]

93. Prakash, C.; Uddin, M.S. Surface modification of $\beta$-phase Ti implant by hydroaxyapatite mixed electric discharge machining to enhance the corrosion resistance and in-vitro bioactivity. Surf. Coat. Technol. 2017, 326, 134-145. [CrossRef]

94. Chen, L.; Wei, K.; Qu, Y.; Li, T.; Chang, B.; Liao, B.; Xue, W. Characterization of plasma electrolytic oxidation film on biomedical high niobium-containing $\beta$-titanium alloy. Surf. Coat. Technol. 2018, 352, 295-301. [CrossRef] 
95. Wang, C.; Ma, F.; Liu, P.; Chen, J.; Liu, X.; Zhang, K.; Li, W.; Han, Q. The influence of alloy elements in Ti 6Al 4V and Ti 35Nb 2Ta 3Zr on the structure, morphology and properties of MAO coatings. Vacuum 2018, 157, 229-236. [CrossRef]

96. Gu, H.; Ding, Z.; Yang, Z.; Yu, W.; Zhang, W.; Lu, W.; Zhang, L.-C.; Wang, K.; Wang, L.; Fu, Y.-f. Microstructure evolution and electrochemical properties of $\mathrm{TiO}_{2} / \mathrm{Ti}-35 \mathrm{Nb}-2 \mathrm{Ta}-3 \mathrm{Zr}$ micro/nano-composites fabricated by friction stir processing. Mater. Des. 2019, 169, 107680. [CrossRef]

97. Liu, C.-F.; Li, S.-J.; Hou, W.-T.; Hao, Y.-L.; Huang, H.-H. Enhancing corrosion resistance and biocompatibility of interconnected porous $\beta$-type Ti-24Nb-4Zr-8Sn alloy scaffold through alkaline treatment and type I collagen immobilization. Appl. Surf. Sci. 2019, 476, 325-334. [CrossRef]

98. Pina, V.G.; Dalmau, A.; Devesa, F.; Amigo, V.; Munoz, A.I. Tribocorrosion behavior of beta titanium biomedical alloys in phosphate buffer saline solution. J. Mech. Behav. Biomed. Mater. 2015, 46, 59-68. [CrossRef]

99. Bahl, S.; Das, S.; Suwas, S.; Chatterjee, K. Engineering the next-generation tin containing beta titanium alloys with high strength and low modulus for orthopedic applications. J. Mech. Behav. Biomed. Mater. 2018, 78, 124-133. [CrossRef]

100. Diomidis, N.; Mischler, S.; More, N.S.; Roy, M.; Paul, S.N. Fretting-corrosion behavior of $\beta$ titanium alloys in simulated synovial fluid. Wear 2011, 271, 1093-1102. [CrossRef]

101. Yuan, Z.; He, Y.; Lin, C.; Liu, P.; Cai, K. Antibacterial surface design of biomedical titanium materials for orthopedic applications. J. Mater. Sci. Technol. 2021, 78, 51-67. [CrossRef]

102. Cai, D.; Zhao, X.; Yang, L.; Wang, R.; Qin, G.; Chen, D.-F.; Zhang, E. A novel biomedical titanium alloy with high antibacterial property and low elastic modulus. J. Mater. Sci. Technol. 2021, 81, 13-25. [CrossRef]

103. Chang, X.; Smith, G.C.; Quinn, J.; Carson, L.; Chan, C.W.; Lee, S. Optimization of anti-wear and anti-bacterial properties of beta TiNb alloy via controlling duty cycle in open-air laser nitriding. J. Mech. Behav. Biomed. Mater. 2020, 110, 103913. [CrossRef]

104. Lubov Donaghy, C.; McFadden, R.; Kelaini, S.; Carson, L.; Margariti, A.; Chan, C.-W. Creating an antibacterial surface on beta TNZT alloys for hip implant applications by laser nitriding. Opt. Laser Technol. 2020, 121, 105793. [CrossRef]

105. Shi, A.; Cai, D.; Hu, J.; Zhao, X.; Qin, G.; Han, Y.; Zhang, E. Development of a low elastic modulus and antibacterial Ti-13Nb-13Zr5Cu titanium alloy by microstructure controlling. Mater. Sci. Eng. C Mater. Biol. Appl. 2021, 126, 112116. [CrossRef]

106. Liu, H.; Liu, R.; Ullah, I.; Zhang, S.; Sun, Z.; Ren, L.; Yang, K. Rough surface of copper-bearing titanium alloy with multifunctions of osteogenic ability and antibacterial activity. J. Mater. Sci. Technol. 2020, 48, 130-139. [CrossRef]

107. Kaur, M.; Singh, K. Review on titanium and titanium based alloys as biomaterials for orthopaedic applications. Mater. Sci. Eng. C Mater. Biol. Appl. 2019, 102, 844-862. [CrossRef]

108. Sidhu, S.S.; Singh, H.; Gepreel, M.A.H. A review on alloy design, biological response, and strengthening of $\hat{\mathrm{I}}^{2}$-titanium alloys as biomaterials. Mater. Sci. Eng. C Biomim. Mater. Sens. Syst. 2021, 121, 111661. [CrossRef]

109. Zhao, D.; Liang, H.; Han, C.; Li, J.; Liu, J.; Zhou, K.; Yang, C.; Wei, Q. 3D printing of a titanium-tantalum Gyroid scaffold with superb elastic admissible strain, bioactivity and in-situ bone regeneration capability. Addit. Manuf. 2021, 47, 102223. [CrossRef]

110. Liang, H.; Zhao, D.; Feng, X.; Ma, L.; Deng, X.; Han, C.; Wei, Q.; Yang, C. 3D-printed porous titanium scaffolds incorporating niobium for high bone regeneration capacity. Mater. Des. 2020, 194, 108890. [CrossRef]

111. Jirka, I.; Vandrovcova, M.; Frank, O.; Tolde, Z.; Plsek, J.; Luxbacher, T.; Bacakova, L.; Stary, V. On the role of Nb-related sites of an oxidized beta-TiNb alloy surface in its interaction with osteoblast-like MG-63 cells. Mater. Sci. Eng. C Mater. Biol. Appl. 2013, 33, 1636-1645. [CrossRef] [PubMed]

112. Li, X.; Chen, T.; Hu, J.; Li, S.; Zou, Q.; Li, Y.; Jiang, N.; Li, H.; Li, J. Modified surface morphology of a novel Ti-24Nb-4Zr-7.9Sn titanium alloy via anodic oxidation for enhanced interfacial biocompatibility and osseointegration. Colloids Surf. B Biointerfaces 2016, 144, 265-275. [CrossRef]

113. Fu, J.; Liu, X.; Tan, L.; Cui, Z.; Liang, Y.; Li, Z.; Zhu, S.; Zheng, Y.; Kwok Yeung, K.W.; Chu, P.K.; et al. Modulation of the mechanosensing of mesenchymal stem cells by laser-induced patterning for the acceleration of tissue reconstruction through the Wnt/beta-catenin signaling pathway activation. Acta Biomater. 2020, 101, 152-167. [CrossRef] [PubMed] 